\title{
Molecular and clinical analyses of Helicobacter pylori colonization in inflamed dental pulp
}

\author{
Ryota Nomura*, Yuko Ogaya, Saaya Matayoshi, Yumiko Morita and Kazuhiko Nakano
}

\begin{abstract}
Background: Recently, dental pulp has been considered a possible source of infection of Helicobacter pylori (H. pylori) in children. We previously developed a novel PCR system for H. pylori detection with high specificity and sensitivity using primer sets constructed based on the complete genome information for $48 \mathrm{H}$. pylori strains. This PCR system showed high sensitivity with a detection limit of 1-10 cells when serial dilutions of $H$. pylori genomic DNA were used as templates. However, the detection limit was lower $\left(10^{2}-10^{3}\right.$ cells) when $H$. pylori bacterial DNA was detected from inflamed pulp specimens. Thus, we further refined the system using a nested PCR method, which was much more sensitive than the previous single PCR method. In addition, we examined the distribution and virulence of $H$. pylori in inflamed pulp tissue.
\end{abstract}

Methods: Nested PCR system was constructed using primer sets designed from the complete genome information of 48 H. pylori strains. The detection limit of the nested PCR system was 1-10 cells using both H. pylori genomic DNA and bacterial DNA isolated from inflamed pulp specimens. Next, distribution of $H$. pylori was examined using 131 inflamed pulp specimens with the nested PCR system. In addition, association between the detection of H. pylori and clinical information regarding endodontic-infected teeth were investigated. Furthermore, adhesion property of $H$. pylori strains to human dental fibroblast cells was examined.

Results: H. pylori was present in 38.9\% of inflamed pulp specimens using the nested PCR system. H. pylori was shown to be predominantly detected in primary teeth rather than permanent teeth. In addition, samplings of the inflamed pulp were performed twice from the same teeth at 1- or 2-week intervals, which revealed that $H$. pylori was detected in most specimens in both samplings. Furthermore, H. pylori strains showed adhesion property to human dental fibroblast cells.

Conclusion: Our results suggest that $\mathrm{H}$. pylori colonizes inflamed pulp in approximately $40 \%$ of all cases through adhesion to human dental fibroblast cells.

Keywords: Helicobacter pylori, Inflamed pulp, Nested PCR method, Human dental fibroblast cells

\section{Background}

Helicobacter pylori is a Gram-negative microaerophilic bacterium found in the stomach that is responsible for gastric diseases [1]. Though details regarding its transmission and infection source remain unclear, the most likely route of infection is through the oral cavity [2]. To detect H. pylori in oral cavity specimens, molecular biological

\footnotetext{
* Correspondence: rnomura@dent.osaka-u.ac.jp

Department of Pediatric Dentistry, Division of Oral Infection and Disease Control, Osaka University Graduate School of Dentistry, 1-8 Yamada-oka, Suita, Osaka 565-0871, Japan
}

(c) The Author(s). 2018 Open Access This article is distributed under the terms of the Creative Commons Attribution 4.0 International License (http://creativecommons.org/licenses/by/4.0/), which permits unrestricted use, distribution, and reproduction in any medium, provided you give appropriate credit to the original author(s) and the source, provide a link to the Creative Commons license, and indicate if changes were made. The Creative Commons Public Domain Dedication waiver (http://creativecommons.org/publicdomain/zero/1.0/) applies to the data made available in this article, unless otherwise stated. technique has been applied [3]. However, it is not easy to estimate the actual infection rate as $H$. pylori detected in the oral cavity has been reported to be $0-100 \%$ [4].

To overcome the difficulty of the detection of H. pylori in the oral specimens, we previously designed novel primer sets based on the information of the complete genome for $48 \mathrm{H}$. pylori strains in the database [5]. We searched genes including $16 \mathrm{~S}$ rRNA, vacA, cagA, glmM (ure $C$ ), and ure $A$ because these genes were used for $H$. pylori detection in published PCR methods with high 
frequency [6-10]. Among these genes, six sequences of at least 20 consecutive nucleotides conserved among all strains were found only in $u r e A$, which were selected as primer sets for the detection. These primer sets produced amplicons for genomic DNA across $H$. pylori strains, but did not for Helicobacter pullorum and Helicobacter felis strains, the closest related species to H. pylori.

Most studies regarding $H$. pylori detection from oral specimens have focused on dental plaque or saliva specimens $[11,12]$. A recent study showed that $H$. pylori was isolated from endodontic-infected root canals of primary teeth [13]. In addition, we detected $H$. pylori bacterial DNA in inflamed pulp specimens using our novel PCR method [5]. In the present study, we refined our system using a nested PCR method, which is much more sensitive than the previous single PCR method. The nested PCR method was then applied to investigate the actual H. pylori distribution in inflamed pulp specimens as well as correlations between the detection of $H$. pylori and clinical information regarding endodontic-infected teeth. Furthermore, the adhesion property of $H$. pylori strains to human dental fibroblast cells, which is considered an important virulence factor of $H$. pylori detected in inflamed pulp, was also investigated.

\section{Method}

\section{Bacterial strains and growth condition}

H. pylori reference strain 26,695 (ATCC 700392), J99 (ATCC 700824), ATCC 51932, and H. pullorum ATCC 51802 were purchased from Summit Pharmaceuticals International Corporation (Tokyo, Japan). H. felis ATCC 49179 was kindly provided by Professor Masakazu Kita (Department of Microbiology, Kyoto Prefectural University of Medicine, Kyoto, Japan). All strains were cultured by the method described previously using blood agar plates (Becton Dickinson, Franklin Lakes, NJ, USA) at $37{ }^{\circ} \mathrm{C}$ for 3 days [5]. Then, single colonies were selected, inoculated in $5 \mathrm{ml}$ tryptic soy broth (Difco Laboratories, Detroit, MI, USA), and incubated at $37{ }^{\circ} \mathrm{C}$ for 3-5 days under microaerophilic conditions.

\section{PCR system for $H$. pylori detection}

$H$. pylori genomic DNA was extracted using a previously reported method for Gram-negative periodontitis-related bacteria [14]. We previously identified six sequences of at least 20 consecutive nucleotides in the ureA gene of $48 \mathrm{H}$. pylori strains registered in the GenBank database [5]. Based on these sequences, five primer sets (ureA-aF/ $\mathrm{aR}$, ure $A-\mathrm{aF} / \mathrm{bR}$, ureA-bF/aR, ureA-bF/bR, ureA-cF/cR) were constructed for PCR methods to detect $H$. pylori [5]. Among these primer sets, two primer sets for the first and second steps of the nested PCR method were selected as follows. First step PCR for $H$. pylori detection was performed using primers ureA-aF ( $5^{\prime}$-ATG AAA CTC ACC CCA AAA GA-3') and ureA-bR (5'- CCG AAA GTT TTT TCT CTG TCA AAG TCT A-3'); second step PCR was performed using primers ureA-bF (5'-AAA CGC AAA GAA AAA GGC ATT AA-3') and ureA-aR (5'-TTC ACT TCA AAG AAA TGG AAG TGT GA-3') (Fig. 1a). First step PCR was performed by amplifying $2 \mu \mathrm{l}$ template genomic DNA extracted from cultured H. pylori strains or bacterial DNA extracted from dental pulp specimens in reactions of $20 \mu \mathrm{l}$ total volume. Second step PCR was performed by amplifying $1 \mu \mathrm{l}$ of the first PCR product used as a template in reactions of $20 \mu \mathrm{l}$ total volume. Both PCR cycles of first and second steps of the nested PCR methods were performed as the single PCR method, described previously using TaKaRa Ex Taq polymerase (Takara Bio. Inc., Otsu, Japan) [5].

\section{Specificity and sensitivity of the first and second step PCR systems}

The specificity of primer sets for $H$. pylori detection was assessed using genomic DNA extracted from H. pylori, H. pullorum, and H. felis. The sensitivity of the PCR assays was determined using titrated cultures of $H$. pylori strain 199. The detection limits of the first step and second step PCR assays were determined using 10-fold serial dilutions of genomic DNA extracted from known numbers of bacterial cells. In addition, five inflamed pulp specimens were taken during root canal treatments. The total numbers of oral bacteria in these specimens were confirmed by plating serially diluted samples onto blood agar plates, which were anaerobically cultured at $37{ }^{\circ} \mathrm{C}$ for 4 days; specimens contained approximately $9 \times 10^{5}-4 \times 10^{6}$ c.f.u. (mean $2.6 \times 10^{6}$ c.f.u.). Among these samples, two $H$. pylori-negative specimens were selected, which were confirmed using the nested PCR method described above. Two dental pulp specimens without bacterial infection were also collected during extraction of completely impacted wisdom teeth. Serial dilutions of known bacterial number of $H$. pylori were added to the inflamed and non-inflamed pulp specimens, followed by DNA extraction. Then, the detection limits of the first and second step PCR assays were determined using bacterial DNA as template.

\section{Dental pulp specimens}

This study was conducted in full adherence to the Declaration of Helsinki. The study protocol was approved by the Ethics Committee of Osaka University Graduate School of Dentistry (approval no. H23-E1-5). Prior to specimen collection, the subjects were informed of the study contents and written informed consent was obtained from all participants. When the participant was 


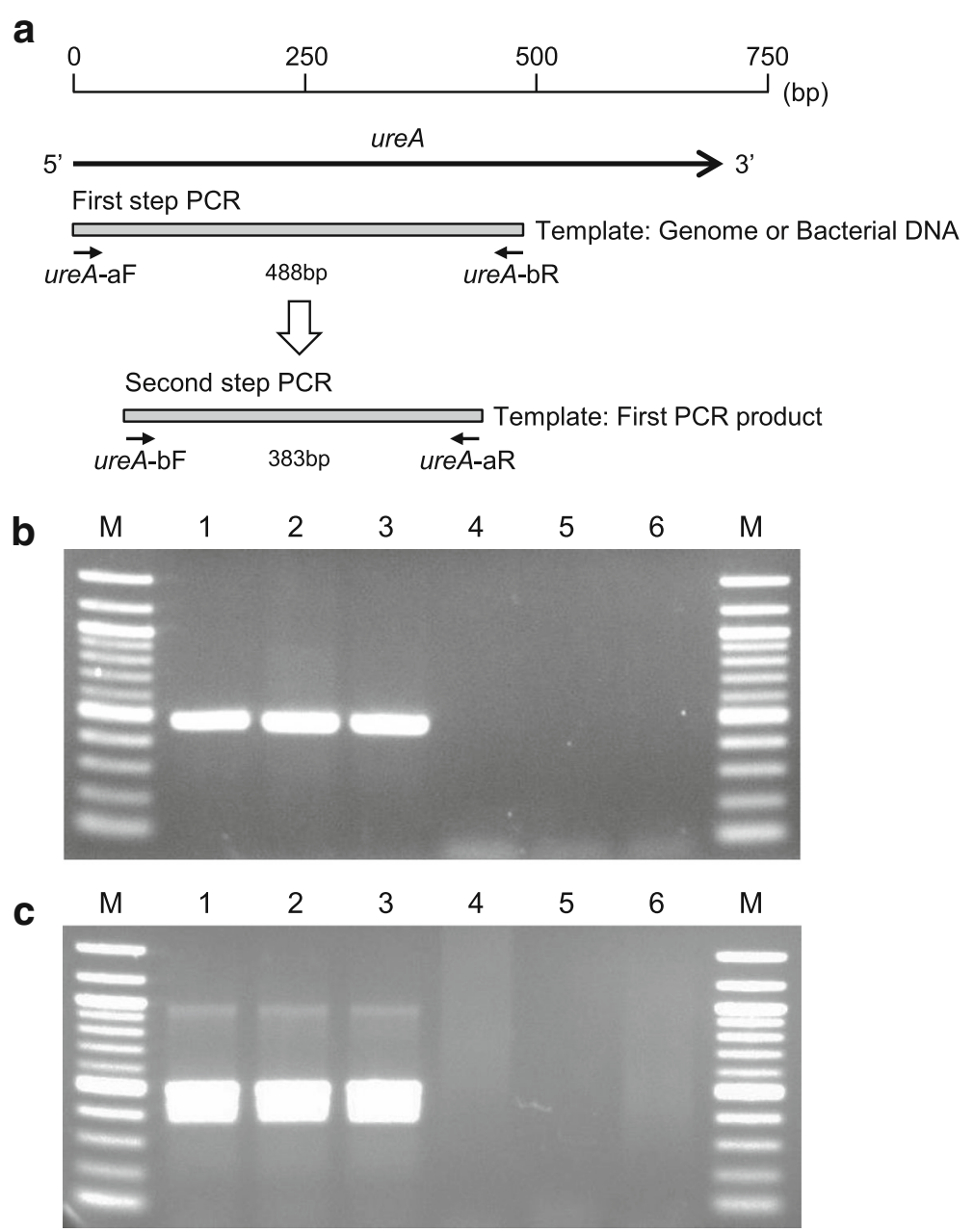

Fig. 1 Nested PCR method for H. pylori detection. a A schematic diagram of positions of the designed primers in this study. b Representative images showing the single PCR assay for $\mathrm{H}$. pylori detection using ureA-aF and ureA-bR primer sets. c Representative images showing the nested PCR assay for $H$. pylori detection using ureA-aF and ureA-bR primer sets, followed by ureA-bF and ureA-aR primer sets. Lanes: 1, H. pylori 26,695; 2, J99; 3, ATCC 51932; 4, H. pullorum ATCC 51802; 5, H. felis ATCC 49179; 6, sterile water. M, molecular size marker (100 bp DNA ladder)

aged under 16, parental written informed consent was also obtained.

Inflamed pulp specimens were obtained from 131 subjects (age range: 1-19 years) who were treated at Osaka University Dental Hospital from February 2013 to February 2016. In our clinic, dental treatments including root canal treatments are performed children aged over 3 or 4 years. However, we performed the root canal treatments to the subjects with lower ages under restraint after the consent of the parents when the subjects have acute symptoms such as spontaneous pain or gingival abscess formation. The specimens were taken from patients who received root canal treatment under local anesthesia because of severe childhood caries $(n=114)$ or trauma $(n=17)$. The 101 and 30 specimens were obtained from primary and permanent teeth, respectively. Among 131 specimens, 36 were used in our previous study [5].
Inflamed pulp specimens taken from different teeth in the same patient were included among the 131 specimens and given a different specimen number.

Among 131 specimens, 20 specimens were taken additional sampling from the same teeth. All 20 specimens were collected from infected root canals with apical abscess formation. First samplings were performed in initial root canal treatments. When a gingival abscess formed, root canals were generally left unsealed and antibiotics were not applied during initial root canal treatments. Thus, second samplings were performed when the subjects visited the hospital for the second root canal treatment $(n=20)$. The detection frequencies of $H$. pylori between first and second samplings were compared.

The sampling method for dental pulp specimens was described previously [5]. The samples were stored on ice and immediately transported to our laboratory for testing. DNA extraction and nested PCR were performed as 
described above. To confirm that the amplified fragments in second step PCR were targeted species, ten positive bands were randomly selected and sequenced as described previously [15].

\section{Adhesion to human dental pulp fibroblast cells (HDPFs)}

The adhesion property of $H$. pylori strains to HDPFs was examined using a method described previously [16], with some modifications. Approximately $1 \times 10^{5} \mathrm{HDPFs}$ were seeded in the tissue culture plates (Costar ${ }^{\circ}$, Corning Inc., Corning, NY, USA). The wells were washed with PBS and antibiotic-free medium was added, followed by the infection of $1 \times 10^{6}$ c.f.u. $H$. pylori in antibiotic-free medium. The medium was removed after $1.5 \mathrm{~h}$ of anaerobic incubation and infected cells were washed with PBS, and then added the sterile distilled water for disruption of the cells. Next, dilutions of cell lysates were plated onto blood agar plates and incubated at $37^{\circ} \mathrm{C}$ for 3 days under microaerophilic conditions. The adhesion rates were calculated by the ratio of resuspended to infected cells. Data are shown as the mean \pm standard deviation of triplicate experiments.

\section{Statistical analyses}

Statistical analyses were performed using the computational software package GraphPad Prism 6 (GraphPad Software Inc., La Jolla, CA, USA). Intergroup differences in each analysis were analyzed using
Bonferroni's method after analysis of variance (ANOVA). A $P$ value of less than 0.05 was considered to be statistically significant.

\section{Results}

\section{Specificity and sensitivity for the first and second step} PCR systems

The first and second step PCR primer sets produced amplicons consistent in size for genomic DNA of all $H$. pylori strains, but were not seen in $H$. pullorum and $H$. felis strains (Fig. 1b, c). The first and second step PCR primer sets showed a level of sensitivity at approximately 1-10 c.f.u. per reaction when $H$. pylori genomic DNA was used as template (Fig. 2a, b). However, the sensitivity of the first step PCR primer sets was decreased $\left(10^{2}-10^{3}\right.$ c.f.u.) when the known number of serially diluted $H$. pylori was added to the infected pulp specimen, whereas the second PCR primer sets maintained a high sensitivity (Fig. 2c, d). Similar results were observed in both the first and second step PCR assays when another inflamed pulp specimen was used (data not shown). Furthermore, the sensitivities of the first and second step PCR primer sets were approximately 1-10 c.f.u. per reaction when the known number of serially diluted $H$. pylori was added to nonbacterial infected pulp specimens, though the bands in the first step PCR were weaker than those obtained from $H$. pylori genomic DNA (Fig. 2e, f). Similar results were observed in both the first and second step PCR assays

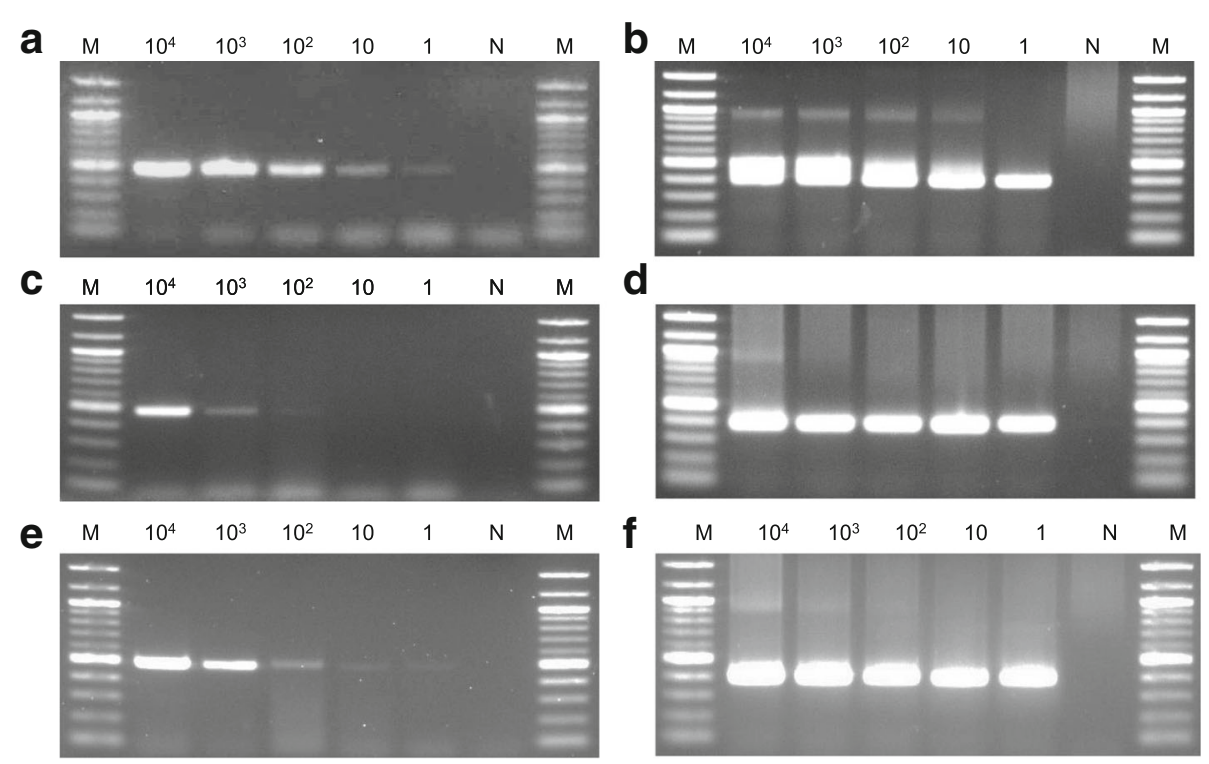

Fig. 2 Sensitivity of the single and nested PCR assays for $H$. pylori detection. Representative images showing the sensitivities of (a) single and (b) second step PCR assays for the detection of H. pylori $J 99$ genomic DNA. Representative images showing the sensitivities of (c) single and (d) second step PCR assays for the detection of $H$. pylori bacterial DNA from inflamed pulp. Representative images showing the sensitivities of (e) single and (f) second step PCR assays for the detection of $H$. pylori bacterial DNA added to non-infected dental pulp. The ureA-aF and ureA-bR primer sets were used for the single PCR assay and ureA-bF and ureA-aR primer sets were used for the second step PCR assay. M, molecular size marker (100 bp DNA ladder) 
when another non-infected pulp specimen was used (data not shown).

\section{H. pylori Detection in inflamed pulp specimens}

Figure $3 \mathrm{a}$ and $\mathrm{b}$ show representative results from the analyses of inflamed pulp specimens using the first and second PCR primer sets. H. pylori was detected in 4 of 131 (3.1\%) root canal specimens in first step PCR, indicating that these samples contained more than $10^{2}-10^{3}$ c.f.u. H. pylori. In second step PCR, 51 (38.9\%) root canal specimens were $H$. pylori-positive, indicating that these samples contained more than 1-10 c.f.u. H. pylori. The nucleotide alignment of the fragment revealed that the second step PCR method could amplify the target sequence of $H$. pylori. The detection rate of $H$. pylori in second step PCR was significantly higher than that in first step PCR $\left({ }^{* * * *} P<0.001\right)$ (Fig. 3c). Additionally, there were no subjects in whom $H$. pylori was detected from all specimens taken from different teeth (Table 1). Among 20 specimens taken from the same teeth, 8 specimens were $H$. pylori-positive in the first sampling, 7 of which were $H$. pylori-positive in the second sampling (Fig. 3d). In addition, only 1 of $12 \mathrm{H}$. pylori-negative specimens showed positive results in the second sampling. There was no significant difference between the detection rate of $H$. pylori in specimens obtained from dental caries and that obtained from trauma (Fig. 3e). The detection rate of $H$. pylori in specimens obtained from primary teeth was higher than that obtained from permanent teeth, though there was no significant difference (Fig. 3f).

\section{H. pylori Adhesion to HDPFs}

All three tested $H$. pylori strains showed adhesion to HDPFs (Fig. 4a). Among these strains, 26,695 showed significantly higher adhesion rates than $199\left({ }^{*} P<0.05\right)$. Confocal scanning laser microscopy demonstrated that $H$. pylori strain 26,695 clearly adhered to HDPFs (Fig. 4b).

\section{Discussion}

The reliable PCR system for the $H$. pylori detection in oral specimens requires high specificity and sensitivity levels since it is known that there are approximately 700 bacterial phylotypes found in the oral cavity [17]. To overcome difficulties in detecting $H$. pylori in the oral cavity, we previously designed novel primer sets using the complete genome information for $48 \mathrm{H}$. pylori strains registered in the GenBank database [5]. In that study, we found six sequences of at least 20 consecutive nucleotides conserved among all strains in the ure $A$ gene. The ureA gene is known to encode the urease enzyme, which has been frequently used to develop PCR primers for $H$. pylori detection $[7,10,18]$. However, no previous ureA-based primers were completely conserved among all strains registered in the database [5].

We previously constructed five primer sets (ureA-aF/ $\mathrm{aR}$, ure $A-\mathrm{aF} / \mathrm{bR}$, ure $A-\mathrm{bF} / \mathrm{aR}$, ure $A-\mathrm{bF} / \mathrm{bR}$, ure $A-\mathrm{cF} / \mathrm{cR})$ for the detection of $H$. pylori based on six sequences of at least 20 consecutive nucleotides [5]. These primer sets showed an appropriate level of sensitivity at approximately 1-10 c.f.u. per reaction for $H$. pylori genomic DNA. However, these primers sets revealed a sensitivity of approximately $10^{2}-10^{3}$ cells for the detection of $\mathrm{H}$. pylori DNA from inflamed pulp specimens. It has been reported that some PCR primers sets showed lower detection limits in $H$. pylori from gastric tissues or oral specimens compared with that from $H$. pylori genomic DNA [11]. In addition, we compared the sensitivities of detecting $H$. pylori from infected pulp specimens versus non-infected pulp specimens by adding a known number of serially diluted $H$. pylori to these specimens using the single PCR methods. The sensitivity in inflamed pulp specimens was much lower than that in non-infected pulp specimens, which indicated that numerous bacteria present at more than $10^{6}$ c.f.u. in inflamed pulp may be the main cause for difficulty in detecting $H$. pylori in such specimens. Thus, we refined our system using a nested PCR method to improve the sensitivity for detection of $H$. pylori DNA from inflamed pulp tissue. Among the five primer sets beased on the ureA gene designed in our previous study, primer sets $u r e A-\mathrm{aF} / \mathrm{bR}$ and $u r e A-b F / a R$ were suitable for the nested PCR method.

Nested PCR is one of the most sensitive methods to detect a small number of bacteria from clinical specimens [19]. The specificity and sensitivity of target DNA amplification is estimated to be approximately $1000-10,000$ times more sensitive than standard PCR [20]. Some researchers previously reported $H$. pylori detection using nested PCR methods [21]. However, complete genome information was unavailable when these nested PCR methods were reported. H. pylori 26,695 (ATCC 700392) is the first strain reported to identify the complete genome sequence in 1997, then only several complete genome sequences of $H$. pylori strains were reported until 10 years ago [22]. To our knowledge, this is the first study to propose a nested PCR method designed based on a large amount of genome information.

The detection rate of $H$. pylori from inflamed pulp specimens detected by single PCR with primer sets ure $A-\mathrm{aF} /$ ure $A$-bR were $3.0 \%$, whereas that with primer set ureA-aF/ureA-aR was $15 \%$ [5]. However, the detection rate using primer set $u r e A-\mathrm{aF} / u r e A-\mathrm{aR}$ was based on the results from only 40 specimens. Thus, the detection rate of the primer set ureA-aF/ureA-aR in $131 \mathrm{spec}$ imens was investigated in the present study, resulting in a detection rate of $5.3 \%$ (data not shown). Though the 


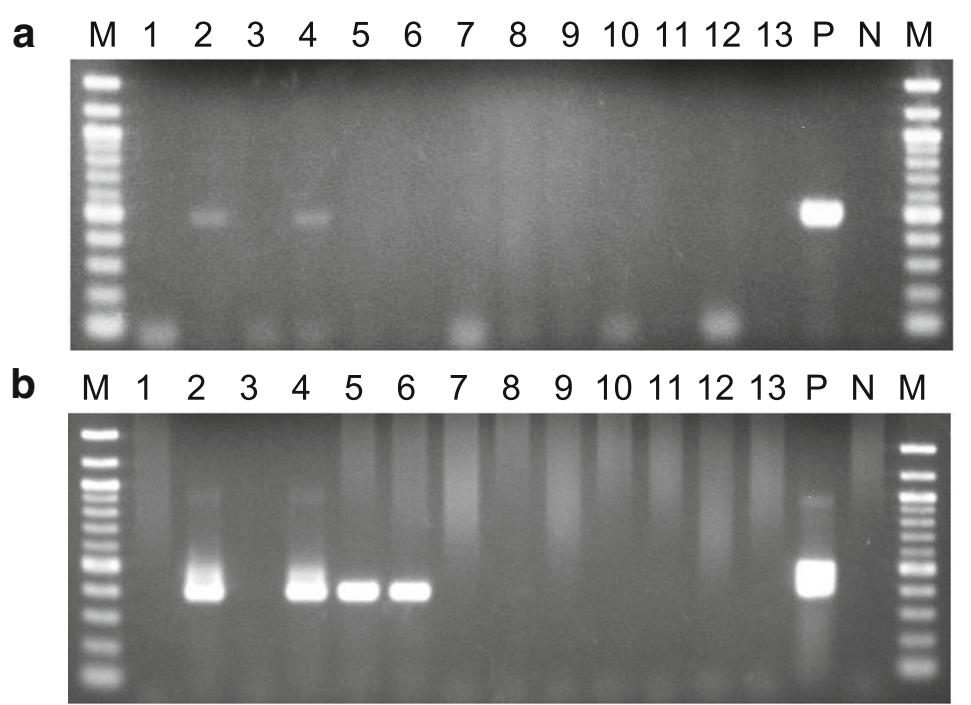

C

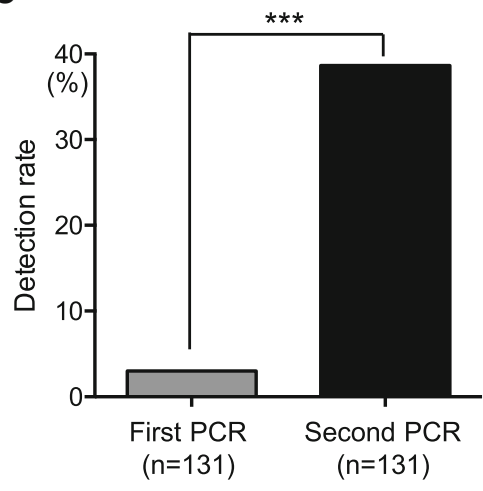

e

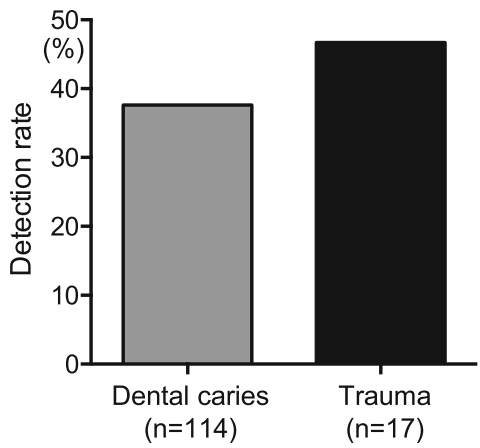

d

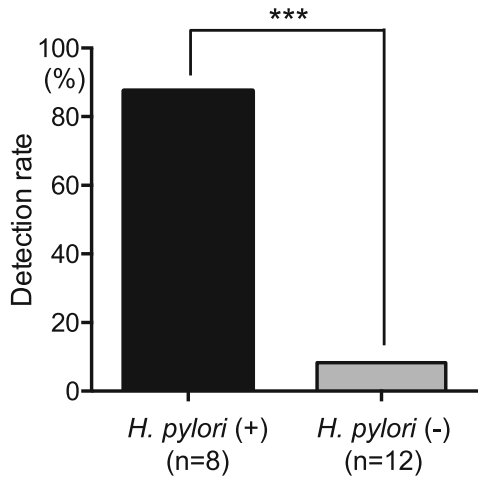

f

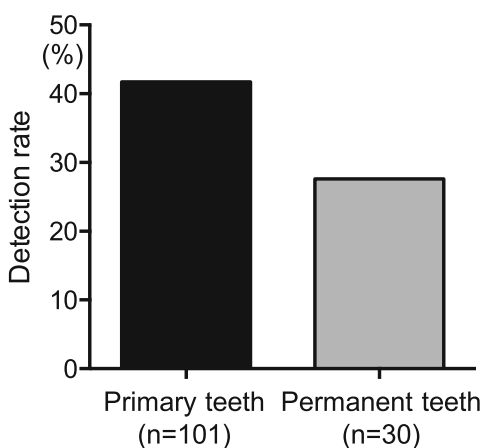

Fig. 3 Detection of $H$. pylori from inflamed pulp specimens using single and nested PCR assays. Representative results using inflamed pulp specimens with (a) single and (b) second step PCR. Lanes 1 through 13 are specimens collected from 13 different individuals; P, H. pylori strains 26,695 (positive control); N, sterile water. M, molecular size marker (100 bp DNA ladder). c Comparison of the detection rates of H. pylori from inflamed pulp specimens using single and second step PCR. $\mathbf{d}$ Detection rates of $H$. pylori in the second sampling from root canal specimens. The groups were categorized as $\mathrm{H}$. pylori-positive or -negative in the first sampling. Comparison of the detection rates of H. pylori from specimens obtained from dental caries verses those from trauma (e) or in comparison between specimens obtained from primary teeth versus permanent teeth (f). Significant differences were determined using Bonferroni's method after ANOVA $(* * * P 0.001)$

detection rate of $H$. pylori with primer set ureA-aF/ureA$\mathrm{aR}$ was higher than that with primer set $u r e A-\mathrm{aF} / u r e A-\mathrm{bR}$, which may be because the primer set ureA-aF/ureA-aR was the most sensitive of all primer combinations [5], the detection limits of both primer sets were similar (approximately 1-10 cells using $H$. pylori genomic DNA). The 
Table 1 Summary of $H$. pylori DNA detection of extirpated inflamed pulp specimens in the subjects who received root canal treatment several times

\begin{tabular}{|c|c|c|c|c|c|}
\hline \multirow{2}{*}{$\frac{\text { Subject }}{1}$} & \multicolumn{4}{|c|}{ Dental caries extending pulp space (Age) } & \multirow{2}{*}{$\frac{\text { Detection Rate }}{0 / 2}$} \\
\hline & ULA (2YOM) & ULB (2Y1M) & & & \\
\hline & - & - & & & \\
\hline \multirow[t]{2}{*}{2} & URA (3Y9M) & URB (3Y9M) & ULA (3Y10M) & & $1 / 3$ \\
\hline & + & - & - & & \\
\hline \multirow[t]{2}{*}{3} & ULD (3Y10M) & URE (3Y11M) & & & $0 / 2$ \\
\hline & - & - & & & \\
\hline \multirow[t]{2}{*}{4} & LLC (4Y7M) & LRC (5Y5M) & & & $1 / 2$ \\
\hline & + & - & & & \\
\hline \multirow[t]{2}{*}{5} & $\operatorname{LLE}(5 Y 1 M)$ & LLD (5Y3M) & & & $0 / 2$ \\
\hline & - & - & & & \\
\hline \multirow[t]{2}{*}{6} & URD (5Y2M) & LLE (5Y3M) & & & $0 / 2$ \\
\hline & - & - & & & \\
\hline \multirow[t]{2}{*}{7} & LLD (6YOM) & LLE (7Y4M) & & & $0 / 2$ \\
\hline & - & - & & & \\
\hline \multirow[t]{2}{*}{8} & URD (6Y2M) & ULD (6Y4M) & URE (6Y5M) & LLE (6Y5M) & $2 / 4$ \\
\hline & + & + & - & - & \\
\hline \multirow[t]{2}{*}{9} & LLD (6Y11M) & LRE (7Y1M) & & & $0 / 2$ \\
\hline & - & - & & & \\
\hline \multirow[t]{2}{*}{10} & LRD (7Y4M) & URD (7Y5M) & LRD (7Y6M) & & $0 / 3$ \\
\hline & - & - & - & & \\
\hline \multirow[t]{2}{*}{11} & LLE (8Y1M) & URD (8Y2M) & & & $0 / 2$ \\
\hline & - & - & & & \\
\hline \multirow[t]{2}{*}{12} & LRE (7Y10M) & LRD (7Y10M) & LLE (7Y11M) & ULE (8YOM) & $2 / 4$ \\
\hline & - & - & + & + & \\
\hline \multirow[t]{2}{*}{13} & LRD (8Y1M) & URD (10Y4M) & & & $1 / 2$ \\
\hline & + & - & & & \\
\hline \multirow[t]{2}{*}{14} & UL1 (9Y1M) & LL1 (10Y5M) & & & $1 / 2$ \\
\hline & - & + & & & \\
\hline \multirow[t]{4}{*}{15} & UR2 (11Y6M) & LR4 (11Y6M) & LR3 (11Y6M) & UL2 (11Y10M) & $2 / 7$ \\
\hline & + & - & - & - & \\
\hline & UL5 (11Y10M) & UR5 (12Y1M) & UR4 (12Y1M) & & \\
\hline & - & + & - & & \\
\hline \multirow[t]{2}{*}{16} & LL5 (14Y10M) & LL7 (14Y10M) & & & $0 / 2$ \\
\hline & - & - & & & \\
\hline
\end{tabular}

URE upper right primary second molar, URD upper right primary first molar, URB upper right primary lateral incisor, URA upper right primary central incisor, ULA upper left primary central incisor, ULB upper left primary lateral incisor, ULD upper left primary first molar, ULE upper left primary second molar, $L L E$ lower left primary second molar, $L L D$ lower left primary first molar, $L L C$ lower left primary canine, $L R C$ lower right primary canine, $L R D$ lower right primary first molar, LRE lower right primary second molar, UR5 upper left second premolar, UR4 upper right first premolar, UR2 upper right lateral incisor, UL1 upper left central incisor, UL2 upper left lateral incisor, UL4 upper left first premolar, UL5 I upper left second premolar, LL7 lower left second molar, LL5 lower left second premolar, LL1 lower left central incisor, LR3 lower right canine

single PCR method using primer set ureA-aF/ureA-aR is a simple and highly sensitive method; however, nested PCR is the most appropriate method for H. pylori detection because it showed highest sensitivity (1-10 cells) and detection rate (38.9\%) in inflamed pulp specimens.
To determine the detailed distribution of $H$. pylori in inflamed pulp tissue, we analyzed the detection rate of $H$. pylori in 16 subjects who received root canal treatment in different teeth. In addition, $H$. pylori detection in 20 subjects with two samplings from the same tooth 


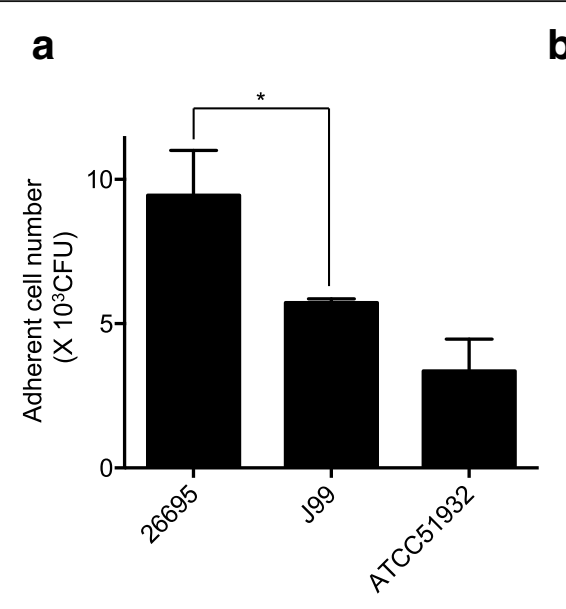

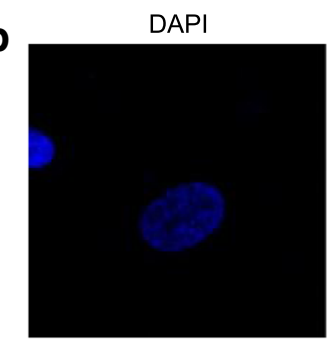

H. pylori
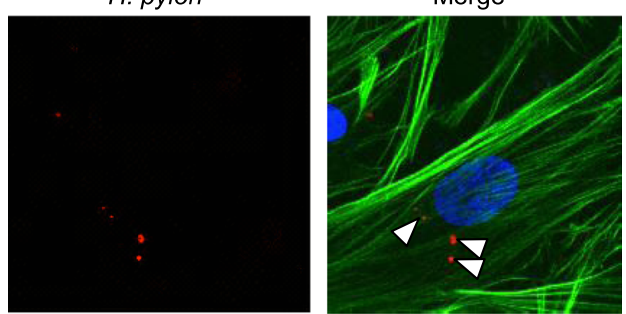

Fig. 4 Adhesion of $H$. pylori strains to human dental pulp fibroblast cells. a Adhesion rates were calculated based on the ratio of recovered to infected strains with an multiplicity of infection of 10 . Significant differences were determined using Bonferroni's method after ANOVA (*P < 0.05). b Representative confocal scanning laser microscopic images of $\mathrm{H}$. pylori strain 26,695 showing adhesion to human dental fibroblast cells following dual labeling. Nuclei are stained blue, bacterial cells adhering to HDPFs are stained red (arrows), and actin filaments are stained green

was performed. H. pylori was not detected from all inflamed pulp specimens in each individual, indicating that $H$. pylori was not widely distributed in teeth with infected root canals. However, most $H$. pylori-positive specimens were positive in the second sampling, suggesting that $H$. pylori was not transiently present but rather colonized the inflamed pulp tissue. Since the intervals between first and second samplings were approximately 1-2 weeks in most subjects, the precise colonization period of $H$. pylori in infected root canal remains unknown. Further studies should be performed to clarify this point. Comparison of the detection rates of $H$. pylori from specimens obtained from primary teeth versus permanent teeth revealed that higher detection rate of $H$. pylori was observed in specimens obtained from primary teeth. The result may be reasonable because $H$. pylori infections seem to be acquired in childhood [2].

Since $H$. pylori was not transiently present in infected root canal, we investigated the mechanism by which $H$. pylori colonizes pulp tissue by analyzing the adhesion property of $H$. pylori to HDPFs. Bacterial adhesion to host cells is considered an important virulence factor for many bacterial species [23]. For $H$. pylori, bacterial adhesion to gastric epithelium is a critical factor for $H$. pylori colonization [24]. However, there have been few reports focusing on $H$. pylori adhesion to cells obtained from oral origin, and, to our knowledge, this is the first study to investigate the adhesion properties of $H$. pylori to HDPFs. All three tested $H$. pylori strains showed adhesion to HDPFs, which is likely one of the reasons why $H$. pylori DNA was detected in inflamed pulp specimens. Among these strains, cagA-positive $H$. pylori strains
26,695 and $J 99$ showed higher adhesion rates compared with cagA-negative $H$. pylori strain ATCC 51932. The cagA gene belongs to the cag pathogenicity island (PAI) [25]. The cag PAI contains several virulence genes, some of which were reported to be related to $H$. pylori adhesion to gastric epithelial cells $[26,27]$. Though cagA is one of the possible genes related to $H$. pylori adhesion, various $H$. pylori adhesins have also been reported [28], and the adhesion mechanisms to HDPFs remain to be elucidated. Further studies should be performed to investigate bacterial adhesion induced by $H$. pylori virulence genes.

\section{Conclusions}

In summary, our nested PCR approach to detect $H$. pylori in inflamed pulp was constructed using two primers sets, both of which were designed based on conserved sequences in $H$. pylori strains. The nested PCR method showed a higher sensitivity than the single PCR method, which used only one primer set. In addition, $H$. pylori strains showed adhesion to HDPFs. These results clearly suggest that $H$. pylori may colonize dental pulp tissue.

\section{Abbreviations}

HDPFs: Human dental fibroblast cells; PBS: Phosphate-buffered saline

\section{Acknowledgements}

We thank Prof. Howard K. Kuramitsu, State University of New York at Buffalo, for editing the manuscript. We also thank Ms. Rewa Yanagisawa, WDB Co., Ltd., for technical support with molecular analyses.

Funding

This work was supported by JSPS KAKENHI Grant Number JP15H05049. 


\section{Availability of data and materials}

The dataset used and/or analyzed during the current study available from the corresponding author on reasonable request.

\section{Authors' contributions}

$\mathrm{RN}$ and $\mathrm{KN}$ designed the study, and experiments were performed by RN, $\mathrm{YO}$, SM and YM. Data interpretation was performed RN and KN. RN wrote the paper under the supervision of KN. All authors read and approved the entire contents of the manuscript.

\section{Ethics approval and consent to participate}

This study was conducted in full adherence to the Declaration of Helsinki. The study protocol was approved by the Ethics Committee of Osaka University Graduate School of Dentistry (approval no. H23-E1-5). Prior to specimen collection, the subjects were informed of the study contents and written informed consent was obtained from all participants. When the participant was aged under 16, parental written informed consent was also obtained.

\section{Competing interests}

The authors declare that they have no competing interests.

\section{Publisher's Note}

Springer Nature remains neutral with regard to jurisdictional claims in published maps and institutional affiliations.

Received: 14 September 2017 Accepted: 9 April 2018

Published online: 16 April 2018

\section{References}

1. Fennerty MB. Helicobacter pylori. Arch Intern Med. 1994;154:721-7.

2. Prasanthi $\mathrm{CH}$, Prasanthi NL, Manikiran SS, Rama-Rao NN. Focus on current trends in the treatment of Helicobacter pylori infection: an update. Inter J Pharm Sci Rev Res. 2011;1:42-51.

3. Westblom TU, Bhatt BD. Diagnosis of Helicobacter pylori infection. Curr Topics Microbiol Immunol. 1999;241:215-35.

4. Silva DG, Tinoco EM, Rocha GA, Rocha AM, Guerra JB, Saraiva IE, Queiroz DM. Helicobacter pylori transiently in the mouth may participate in the transmission of infection. Mem Inst Oswaldo Cruz. 2010:105:657-60.

5. Ogaya Y, Nomura R, Watanabe Y, Nakano K. Detection of Helicobacter pylori DNA in inflamed dental pulp specimens from Japanese children and adolescents. J Med Microbiol. 2015:64:117-23.

6. Mapstone NP, Lynch DA, Lewis FA, Axon AT, Tompkins DS, Dixon MF, Quirke P. Identification of Helicobacter pylori DNA in the mouths and stomachs of patients with gastritis using PCR. J Clin Pathol. 1993;46:540-3.

7. Miyabayashi H, Furihata K, Shimizu T, Ueno I, Akamatsu T. Influence of ora Helicobacter pylori on the success of eradication therapy against gastric Helicobacter pylori. Helicobacter. 2000:5:30-7.

8. Wang J, Chi DS, Laffan JJ, Li C, Ferguson DA Jr, Litchfield P, Thomas E. Comparison of cytotoxin genotypes of Helicobacter pylori in stomach and saliva. Dig Dis Sci. 2002;47:1850-6.

9. Park CY, Kwak M, Gutierrez O, Graham DY, Yamaoka Y. Comparison of genotyping Helicobacter pylori directly from biopsy specimens and genotyping from bacterial cultures. J Clin Microbiol. 2003;41:3336-8.

10. Smith SI, Oyedeji KS, Arigbabu AO, Cantet F, Megraud F, Ojo OO, Uwaifo AO, Otegbayo JA, Ola SO, Coker AO. Comparison of three PCR methods for detection of Helicobacter pylori DNA and detection of cagA gene in gastric biopsy specimens. World J Gastroenterol. 2004;10:1958-60.

11. Sugimoto M, Wu JY, Abudayyeh $\mathrm{S}$, Hoffman J, Brahem $\mathrm{H}$, Al-Khatib K, Yamaoka Y, Graham DY. Unreliability of results of PCR detection of Helicobacter pylori in clinical or environmental samples. J Clin Microbiol. 2009; $47: 738-42$

12. Aksit Bıcak D, Akyuz S, Kıratlı B, Usta M, Urganci N, Alev B, Yarat A, Sahin F. The investigation of Helicobacter pylori in the dental biofilm and saliva samples of children with dyspeptic complaints. BMC Oral Health. 2017;17:67.

13. Hirsch C, Tegtmeyer N, Rohde M, Rowland M, Oyarzabal OA, Backert S. Live Helicobacter pylori in the root canal of endodontic-infected deciduous teeth. J Gastroenterol. 2012:47:936-40.

14. Amano A, Nakagawa I, Kataoka K, Morisaki I, Hamada S. Distribution of Porphyromonas gingivalis strains with fimA genotypes in periodontitis patients. J Clin Microbiol. 1999;37:1426-30.
15. Nakano K, Inaba H, Nomura R, Nemoto H, Takeda M, Yoshioka H, Matsue $H$, Takahashi T, Taniguchi K, et al. Detection of cariogenic Streptococcus mutans in extirpated heart valve and atheromatous plaque specimens. J Clin Microbiol. 2006:44:3313-7.

16. Nomura R, Ogaya Y, Nakano K. Contribution of the collagen-binding proteins of Streptococcus mutans to bacterial colonization of inflamed dental pulp. PLoS One. 2016;11:e0159613.

17. Robert J, Palmer JR. Composition and development of oral bacterial communities. Periodontol. 2013:64:20-39.

18. Peek RM Jr, Miller GG, Tham KT, Pérez-Pérez Gl, Cover TL, Atherton JC, Dunn GD, Blaser MJ. Detection of Helicobacter pylori gene expression in human gastric mucosa. J Clin Microbiol. 1995;33:28-32.

19. Yamamoto Y. PCR in diagnosis of infection: detection of bacteria in cerebrospinal fluids. Clin Diagn Lab Immunol. 2002;9:508-14.

20. Takahashi T, Nakayama T, Tamura M, Ogawa K, Tsuda H, Morita A, Hara M, Togo M, Shiota $\mathrm{H}$, et al. Nested polymerase chain reaction for assessing the clinical course of tuberculous meningitis. Neurology. 2005;64:1789-93.

21. Umeda M, Kobayashi H, Takeuchi Y, Hayashi J, Morotome-Hayashi Y, Yano K, Aoki A, Ohkusa T, Ishikawa I. High prevalence of Helicobacter pylori detected by PCR in the oral cavities of periodontitis patients. J Periodontol. 2003;74: 129-34.

22. Oh JD, Kling-Bäckhed $H$, Giannakis $M, X u$ J, Fulton RS, Fulton LA, Cordum HS, Wang C, Elliott G, et al. The complete genome sequence of a chronic atrophic gastritis Helicobacter pylori strain: evolution during disease progression. Proc Natl Acad Sci U S A. 2006;103:9999-10004.

23. Ribet D, Cossart P. How bacterial pathogens colonize their hosts and invade deeper tissues. Microbes Infect. 2015;17:173-83.

24. Sheu BS, Yang HB, Yeh YC, Wu JJ. Helicobacter pylori colonization of the human gastric epithelium: a bug's first step is a novel target for us. J Gastroenterol Hepatol. 2010;25:26-32.

25. Jones KR, Whitmire JM, Merrell DS. A tale of two toxins: Helicobacter Pylori CagA and VacA modulate host pathways that impact disease. Front Microbiol. 2010;1:115.

26. Rieder G, Hatz RA, Moran AP, Walz A, Stolte M, Enders G. Role of adherence in interleukin-8 induction in Helicobacter pylori-associated gastritis. Infect Immun. 1997;65:3622-30.

27. Segal ED, Lange C, Covacci A, Tompkins LS, Falkow S. Induction of host signal transduction pathways by Helicobacter pylori. Proc Natl Acad Sci U S A. 1997:94:7595-9.

28. Ghosh P, Sarkar A, Ganguly M, Raghwan Alam J, De R, Mukhopadhyay AK. Helicobacter pylori strains harboring babA2 from Indian sub population are associated with increased virulence in ex vivo study. Gut Pathog. 2016;8:1.

\section{Ready to submit your research? Choose BMC and benefit from:}

- fast, convenient online submission

- thorough peer review by experienced researchers in your field

- rapid publication on acceptance

- support for research data, including large and complex data types

- gold Open Access which fosters wider collaboration and increased citations

- maximum visibility for your research: over $100 \mathrm{M}$ website views per year

At BMC, research is always in progress.

Learn more biomedcentral.com/submissions 